\title{
Some Aspects of Metabolism and Mutagenicity of o-Tolidine and an o-Tolidine-based Azo Dye
}

\author{
Ken-ichi TANAKA*, Toshiko MII*, Shogo MARUI*, \\ Ikuo MATSUBARA** and Hiroyuki IGAKI** \\ * Toxicology Laboratory, Research and Development Planning Department, \\ Toray Industries Inc., 2-7-35 Sonoyama, Otsu, 520 Japan \\ **Toray Research Center, Inc., 1,111 Tebiro, Kamakura, 248 Japan
}

(Received April 14, 1982 and in revised form June 11, 1982)

\begin{abstract}
Mutagenicity of the urine extracts of the rats to which either $o$-tolidine or Evans Blue, an o-tolidine-based azo dye, had been orally given was assayed in the Salmonella/mammalian-microsome test. The urine extracts obtained from the rats treated with o-tolidine showed stronger mutagenicity than o-tolidine itself. While Evans Blue did not show mutagenicity at all, the urine extracts derived from the substance were found mutagenic. Both $3,3^{\prime}$-dimethyl- $N$-acetylbenzidine and $3,3^{\prime}$-dimethyl- $N, N^{\prime}$-diacetylbenzidine were identified as urinary metabolites of o-tolidine. They were found not only in the urine of the rats treated with $o$ tolidine but also in the urine of the rats to which Evans Blue had been orally administered. The experimental results suggest that the accidental intake of biphenyl-based dyestuffs through the mouth should be cautiously avoided. Some aspects of the metabolism of $o$-tolidine and Evans Blue are discussed along with the problem associated with the mutagenic activities of the o-tolidine metabolites.
\end{abstract}

Keywords: $o$-tolidine-3, 3'-dimethyl- $N$-acetylbenzidine-3, $3^{\prime}$-dimethyl- $N, N^{\prime}$-diacetylbenzidine-Evans Blue-Benzidine- $N$-acetylbenzidine $-N, N^{\prime}$-diacetylbenzidine-Mutagenicity-Urinary metabolites

\section{INTRODUCTION}

In recent years increasing attention has been paid to biphenyl-based dyestuffs in the field of occupational health. In 1979 the National Institute for Occupational Safety and Health, USA, warned that the use of benzidine-based dyestuffs should be discontinued because of a cancer risk ${ }^{1,2)}$.

We lately reported that $N$-acetylated metabolites of benzidine could be found not only in the urine of the rats to which some azo dyes containing the $4,4^{\prime}-$ diazobiphenyl group had been orally given but also in the urine of men who had undergone gastroscopy with one of the dyes ${ }^{3)}$.

In the present study we have found that $3,3^{\prime}$-dimethyl- $N$-acetylbenzidine and 
3,3'-dimethyl- $N, N^{\prime}$-diacetylbenzidine can be detected as urinary metabolites of $o$-tolidine(3,3'-dimethylbenzidine). We have also found that these $o$-tolidine metabolites can be found in the urine of the rats to which Evans Blue, an $o$-tolidinebased azo dye, had been orally administered.

\section{Materials ANd Methods}

Chemicals: o-Tolidine and Evans Blue, or 4,4'-bis[7-(1-amino-8-hydroxy-2,4disulfo)naphthylazo]3,3'-bitolyl tetrasodium salt, were purchased from Wako Pure Chemical Industries Ltd., Osaka, Japan. Benzidine was given by the Engineering Research Laboratory, Toray Industries, Inc. 3,3'-Dimethyl- $N$-acetylbenzidine $\left(\mathrm{CH}_{3}-\mathrm{AB}\right), 3,3^{\prime}$-dimethyl- $N, N^{\prime}$-diacetylbenzidine $\left(\mathrm{CH}_{3}\right.$-DAB $), N$-acetylbenzidine (AB), and $N, N^{\prime}$-diacetylbenzidine(DAB) were synthesized through the reaction of acetic acid anhydride with either $o$-tolidine or benzidine. Characterization of these compounds is listed in Table 1.

Urine extracts: o-Tolidine and Evans Blue were respectively intubated into the stomachs of male Sprague-Dawley rats weighing $300 \mathrm{~g}$ approximately. The given dose was $50 \mathrm{mg} / \mathrm{kg}$ for the former and $300 \mathrm{mg} / \mathrm{kg}$ for the latter. Urine was collected during the first $24 \mathrm{~h}$. It was adjusted to $p \mathrm{H} 7$ with $1 \mathrm{~N} \mathrm{HCl}$ or $1 \mathrm{~N} \mathrm{NaOH}$ and was extracted twice with the same amount of ether. After the ether had been evaporated, the dried residue was obtaind as urine extracts.

Mutagenicity assay: Mutagenicity of both the urine extracts obtained from the rats and the chemicals themselves was assayed in the Salmonella/mammalianmicrosome test developed by Ames et al. ${ }^{4)}$ with the modification of Yahagi et al. ${ }^{5}$ )

Salmonella typhimurium TA98 and TA100 were employed as the tester strains. A S9 mix was prepared from male Sprague-Dawley rats treated with polychlorinated biphenyl.

Analysis of urine extracts: Analyses of the urine extracts were carried out by gas chromatography (GC) and high-performance liquid chromatography (HPLC). The conditions were as follows. GC-Gas chromatograph: Hewlett-Packard 5840A equipped with a flame ionization detector and a nitrogen-phosphorous detector; Column: 3 feet $\times 2 \mathrm{~mm}$ i.d. glass column arranged for on column injection and packed with OV-17 on 80/100 mesh Chromosorb W (AW-DMCS); Oven temperature: $150^{\circ} \mathrm{C} \rightarrow 280^{\circ} \mathrm{C}$, at $6^{\circ} \mathrm{C} / \mathrm{min}$; Carrier: nitrogen at $18 \mathrm{ml} / \mathrm{min}$. HPLC_pump: Altex 110A; Column: 1 feet $\times 4 \mathrm{~mm}$ i.d. stainless steel column packed with $\mathrm{M}$. Nagel Nucleosil $10 \mathrm{C}_{18}$; Injector: Rheodyne 7125; Detector: Shimadzu SPD-1 operated at $280 \mathrm{~nm}$; Column temperature: ambient; Mobile phase: gradient elution of water (containing $0.01 \mathrm{M} \mathrm{KH}_{2} \mathrm{PO}_{4}$ ) and tetrahydrofuran $80 / 20$ to $50 / 50$ at $2.5 \% / \mathrm{min}$; Flow rate: $1 \mathrm{ml} / \mathrm{min}$. 


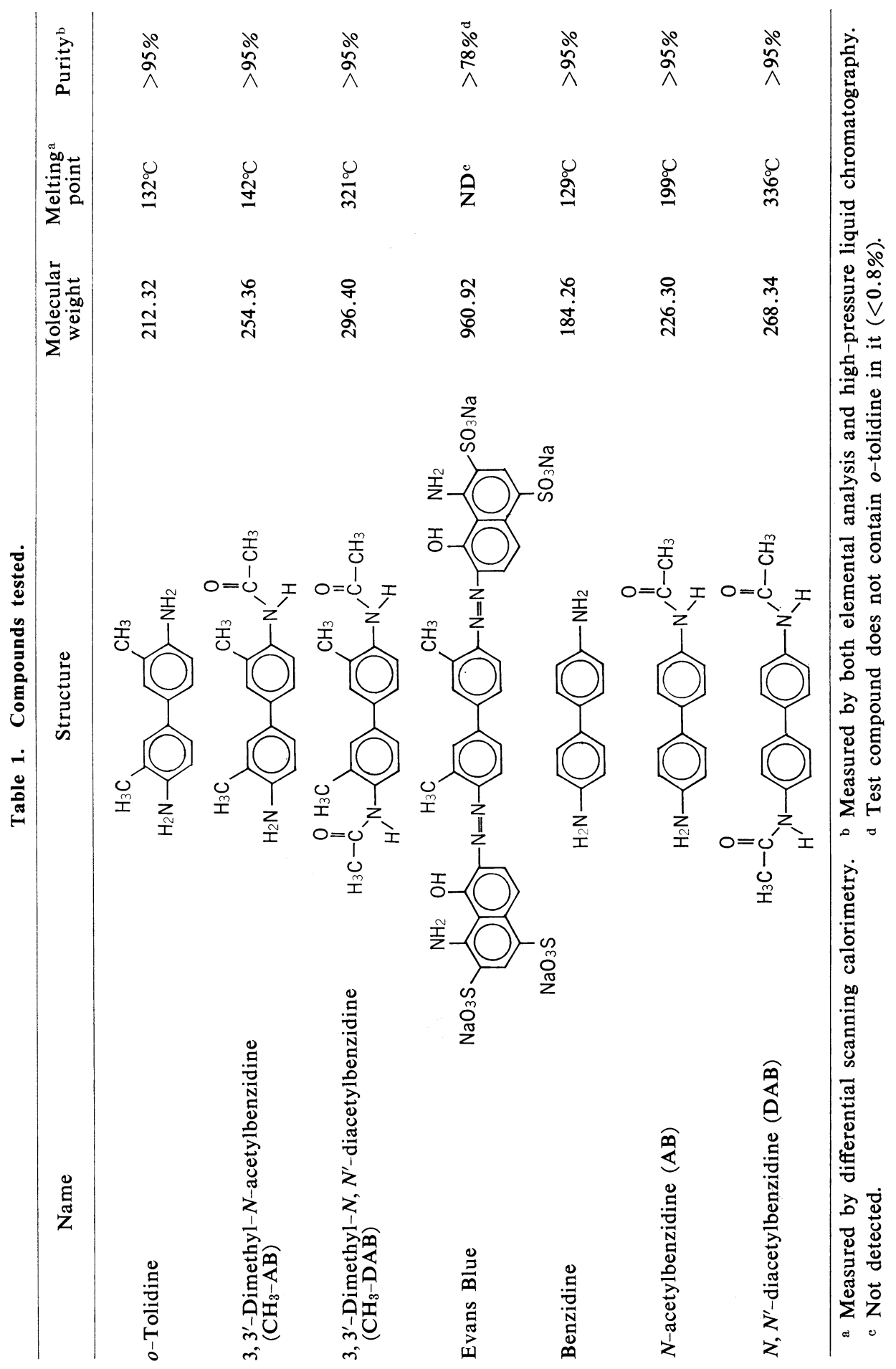




\section{Results AND Discussion}

Table 2 shows the mutagenic activities of $o$-tolidine and Evans Blue along with those of the urine extracts obtained from the rats which had been treated with either of the substances. The urine extracts derived from $o$-tolidine exhibited stronger mutagenicity than $o$-tolidine itself. While Evans Blue itself was not mutagenic, the urine extracts derived from Evans Blue showed mutagenicity.

The GC and HPLC analyses revealed that both $\mathrm{CH}_{3}-\mathrm{AB}$ and $\mathrm{CH}_{3}-\mathrm{DAB}$ can be found with or without $o$-tolidine not only in the urine of the rats treated with $o$-tolidine but also in the urine of the rats to which Evans Blue had been orally given (see Figs. 1, 2 and Table 3 ).

Table 4 shows the mutagenic activities of the chemicals synthesized as metabolites of $o$-tolidine or benzidine. While both $\mathrm{AB}$ and $\mathrm{DAB}$ presented strong mutagenicity in the presence of $\mathrm{S} 9 \mathrm{mix}$, the mutagenic activities of $\mathrm{CH}_{3}-\mathrm{DAB}$ were weaker than those of $\mathrm{CH}_{3}-\mathrm{AB}$.

The urine extracts obtained from the experimental animals contain not only the metabolites of the given chemical but also various substances of different origin, as we already reported in a previous paper ${ }^{6)}$. How much of the extract consists of the metabolites of the given chemical cannot easily be estimated. However, if the urine extract as a whole showed stronger mutagenicity than the corresponding chemical, we could assume that there was at least a metabolite whose mutagenic activity was stronger than the original chemical.

Table 2. Mutagenicity of o-tolidine, Evans Blue, and urine extracts (UE) from rats treated with o-tolidine or Evans Blue

\begin{tabular}{|c|c|c|c|c|c|}
\hline \multirow{2}{*}{ Test Sample } & \multirow{2}{*}{$\begin{array}{c}\text { Dose } \\
(\mu \mathrm{g} / \text { plate })\end{array}$} & \multicolumn{4}{|c|}{$\mathrm{His}^{+}$revertants per plate } \\
\hline & & TA $98-\mathrm{S} 9$ & TA $98+$ S 9 & TA $100-\mathrm{S} 9$ & $\mathrm{TA} 100+\mathrm{S} 9$ \\
\hline Noneb & - & 22 & 26 & 145 & 137 \\
\hline \multirow[t]{3}{*}{$o$-Tolidine } & 50 & 20 & 129 & 156 & 151 \\
\hline & 200 & 19 & 246 & 146 & 214 \\
\hline & 500 & 21 & 604 & 136 & 211 \\
\hline \multirow[t]{3}{*}{ Evans Blue } & 50 & 23 & 32 & 136 & 118 \\
\hline & 200 & 24 & 19 & 142 & 124 \\
\hline & 500 & 27 & 21 & 137 & 120 \\
\hline $\mathrm{UE}($ Control)c & 500 & 24 & 24 & 132 & 130 \\
\hline \multirow[t]{3}{*}{ UE $(o \text {-tolidine })^{\mathrm{d}}$} & 50 & 269 & 524 & 202 & 216 \\
\hline & 200 & 262 & 1,482 & 332 & 552 \\
\hline & 500 & 247 & 3,500 & 408 & 978 \\
\hline \multirow[t]{3}{*}{ UE (Evans Blue) } & 50 & 19 & 89 & 136 & 114 \\
\hline & 200 & 21 & 327 & 123 & 123 \\
\hline & 500 & 32 & 744 & 143 & 143 \\
\hline
\end{tabular}

a Average of 3 separate Expts.

b Negative control.

c Urine extract obtained from a rat to which no chemical was given.

d Urine extract obtained from a rat to which $o$-tolidine was given. 

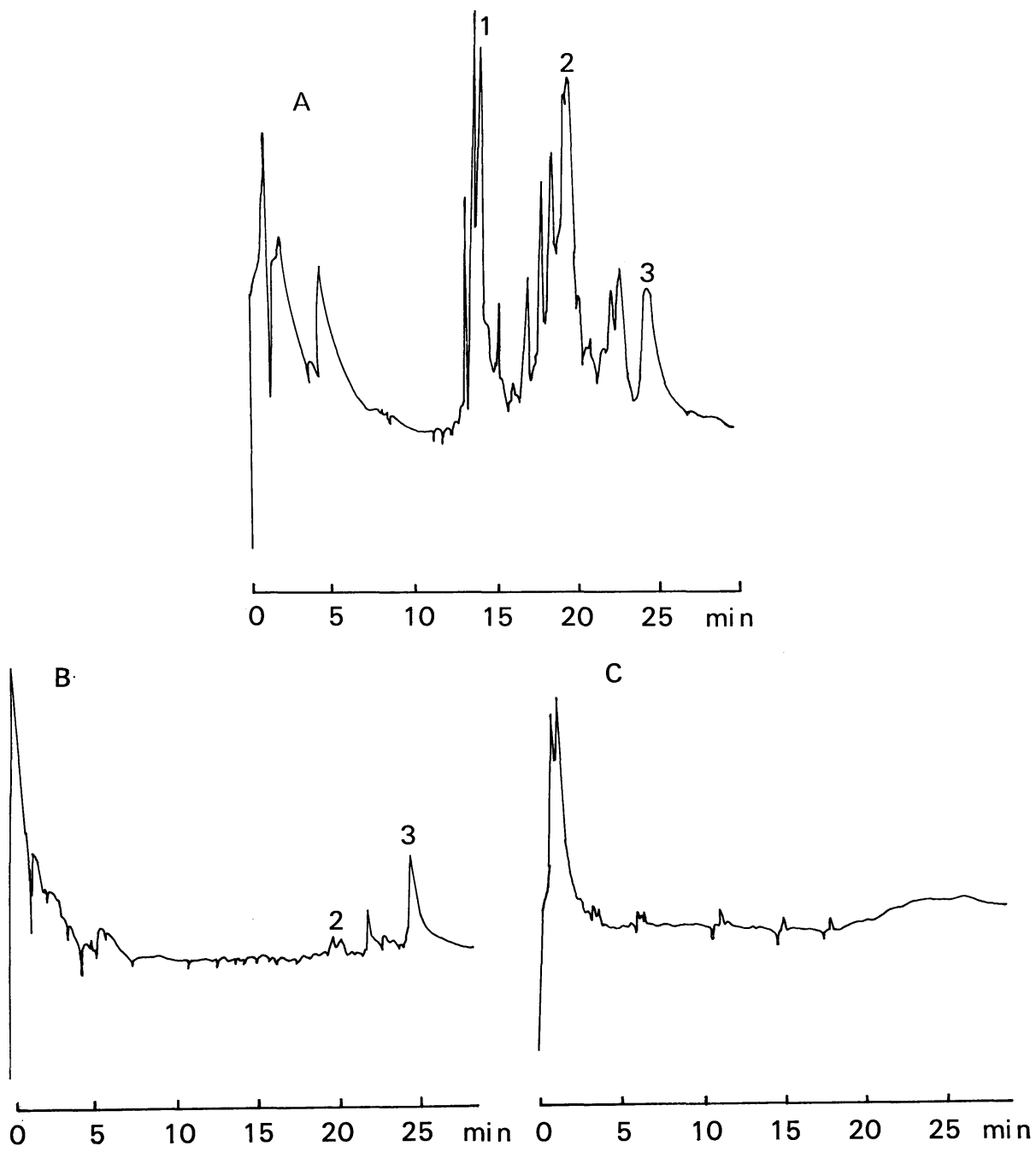

Fig. 1. Gas chromatograms of urine extracts from three rats treated with $o$-tolidine (A), Evans Blue (B), and none $(C)$, respectively.

Peaks 1, 2, and 3 show $o$-tolidine, 3, $3^{\prime}$-dimethyl- $N$-acetylbenzidine $\left(\mathrm{CH}_{3}{ }^{-}\right.$ $\mathrm{AB})$, and $3,3^{\prime}$-dimethyl-N, $N^{\prime}$-diacetylbenzidine $\left(\mathrm{CH}_{3}-\mathrm{DAB}\right)$.

The experimental results shown in Table 2 suggest that $o$-tolidine metabolites which have stronger mutagenicities than $o$-tolidine itself exist in the urine extracts of the rats treated with $o$-tolidine.

In our preliminary test it was found that the recovery of $o$-tolidine, $\mathrm{CH}_{3}-\mathrm{AB}$, and $\mathrm{CH}_{3}$-DAB from the urine with ether extraction was not excellent. In this sense, the amount of $\mathrm{CH}_{3}-\mathrm{AB}$ and $\mathrm{CH}_{3}-\mathrm{DAB}$ demonstrated in Table 3 may not give accurate information of their concentrations in the urine, although the amounts themselves as the contents of the urine extracts are exact enough. How- 


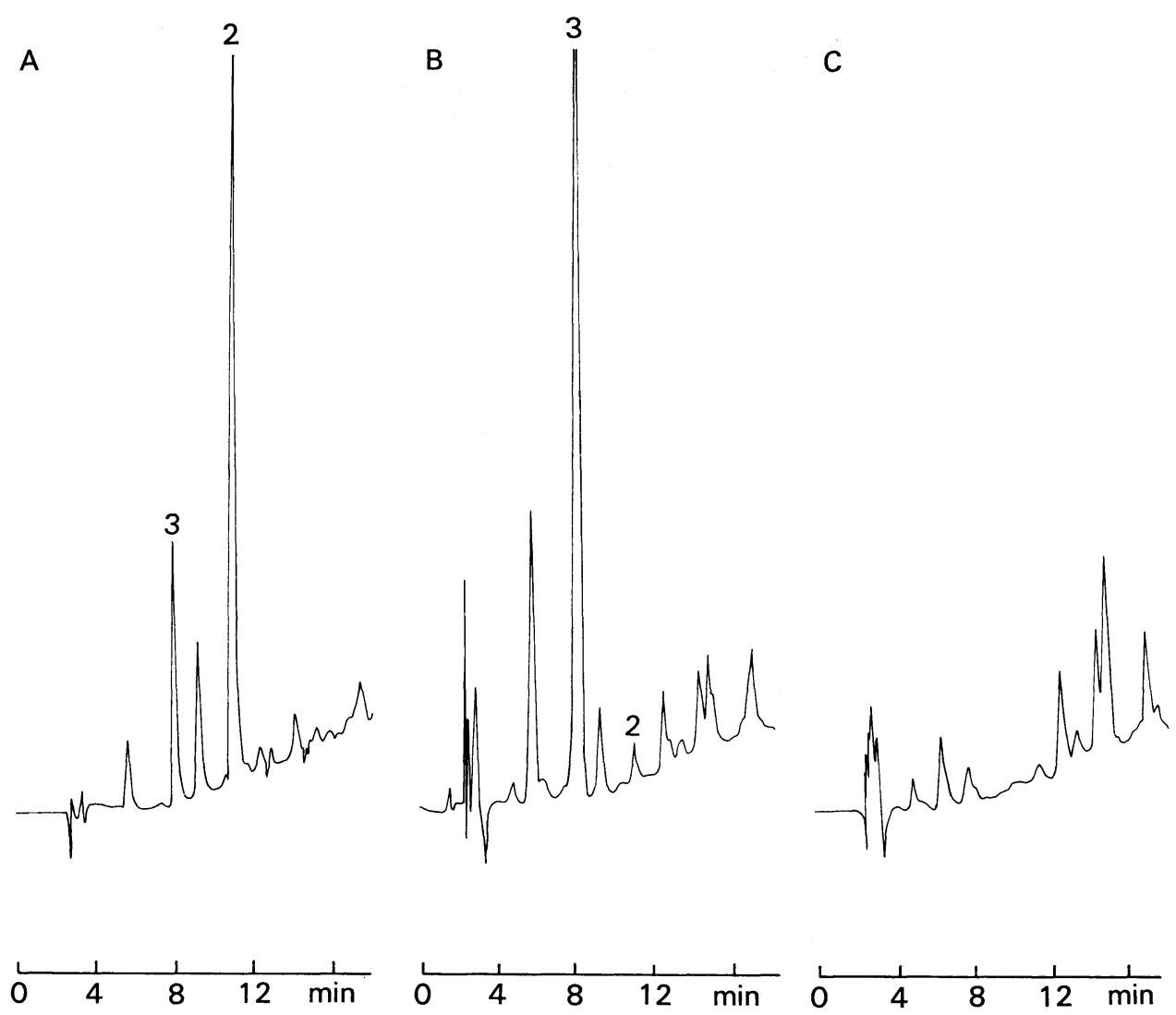

Fig. 2. Liquid chromatograms of the same urine samples as shown in Fig. 1. Peak number is the same as in Fig. 1.

Table 3. Amount of urine extracts obtained from $24 \mathrm{~h}$ urine and that of $o$-tolidine metabolites in the extracts (Mean \pm SD)

\begin{tabular}{|c|c|c|c|c|c|c|c|}
\hline \multirow{2}{*}{ Chemical } & \multirow{2}{*}{$\begin{array}{c}\text { Number } \\
\text { of } \\
\text { animals }\end{array}$} & \multirow{2}{*}{$\begin{array}{c}\text { Given } \\
\text { dose } \\
(\mathrm{mg} / \mathrm{kg})\end{array}$} & \multirow{2}{*}{$\begin{array}{l}\text { Urine } \\
\text { volume } \\
(\mathrm{m} l)\end{array}$} & \multirow{2}{*}{$\begin{array}{l}\text { Urine } \\
\text { extracts } \\
\text { (mg) }\end{array}$} & \multicolumn{3}{|c|}{$\begin{array}{c}o \text {-Tolidine and its metabolites in } \\
\text { urine extracts }(\mathrm{mg})\end{array}$} \\
\hline & & & & & $o$-Tolidine & $\mathrm{CH}_{3}-\mathrm{AB}^{\mathrm{a}}$ & $\mathrm{CH}_{3}-\mathrm{DAB}^{\mathrm{b}}$ \\
\hline$o$-Tolidine & 6 & 50 & $28 \pm 5$ & $10 \pm 3$ & $0.016 \pm 0.006$ & $0.33 \pm 0.21$ & $0.31 \pm 0.08$ \\
\hline Evans Blue & 6 & 300 & $30 \pm 10$ & $8 \pm 4$ & $\mathrm{ND}^{\mathrm{c}}$ & $0.002 \pm 0.001$ & $0.070 \pm 0.02$ \\
\hline Control & 10 & - & $27 \pm 11$ & $3 \pm 2$ & ND & ND & ND \\
\hline
\end{tabular}

a $3,3^{\prime}$-Dimethyl- $N$-acetylbenzidine.

b $3,3^{\prime}$-Dimethyl- $N, N^{\prime}$-diacetylbenzidine.

c Not detected $(<0.01 \mathrm{mg})$

ever, the experimental results exhibit that $\mathrm{CH}_{3}-\mathrm{AB}$ and $\mathrm{CH}_{3}-\mathrm{DAB}$ which have analogous structures to those of benzidine metabolites, $\mathrm{AB}$ and $\mathrm{DAB}$ respectiveiy, are $o$-tolidine metabolites which are excreted in the urine.

In recent years information has been increasing with respect to the metabolism 
Table 4. Comparative studies on mutagenic potency of benzidine and $o$-tolidine metabolites.

\begin{tabular}{|c|c|c|c|c|c|}
\hline \multirow[b]{2}{*}{ Test sample } & \multirow{2}{*}{$\begin{array}{c}\text { Dose } \\
(\mu \mathrm{g} / \text { plate })\end{array}$} & \multicolumn{4}{|c|}{$\mathrm{His}^{+}$revertants per plate ${ }^{\mathrm{a}}$} \\
\hline & & $\begin{array}{l}\text { TA } 98 \\
- \text { S } 9\end{array}$ & $\begin{array}{l}\text { TA } 98 \\
+ \text { S } 9\end{array}$ & $\begin{array}{l}\text { TA } 100 \\
-S 9\end{array}$ & $\begin{array}{l}\text { TA } 100 \\
+ \text { S } 9 \\
\end{array}$ \\
\hline None $^{b}$ & - & 24 & 29 & 123 & 119 \\
\hline \multirow[t]{3}{*}{ Benzidine } & 10 & 22 & 109 & 128 & 132 \\
\hline & 50 & 24 & 365 & 124 & 254 \\
\hline & 200 & 27 & 895 & 140 & 456 \\
\hline \multirow[t]{3}{*}{$N$-Acetylbenzidine (AB) } & 10 & 20 & 714 & 142 & 254 \\
\hline & 50 & 18 & 1,950 & 127 & 625 \\
\hline & 200 & 21 & 3,354 & 144 & 1,613 \\
\hline \multirow[t]{3}{*}{$N, N^{\prime}$-Diacetylbenzidine (DAB) } & 10 & 20 & 657 & 136 & 264 \\
\hline & 50 & 18 & 1,692 & 123 & 893 \\
\hline & 200 & 21 & 2,615 & 119 & 1,512 \\
\hline \multirow{3}{*}{$\begin{array}{l}\text { 3, } 3^{\prime} \text {-Dimethyl-N-acetylbenzidine } \\
\left(\mathrm{CH}_{3}-\mathrm{AB}\right)\end{array}$} & 10 & 26 & 746 & 136 & 284 \\
\hline & 50 & 19 & 1,211 & 127 & 699 \\
\hline & 200 & 29 & 3,304 & 144 & 1,256 \\
\hline \multirow{3}{*}{$\begin{array}{l}\text { 3, 3'-Dimethyl- } N, N^{\prime} \text {-diacetylbenzidine } \\
\left(\mathrm{CH}_{3}-\mathrm{DAB}\right)\end{array}$} & 10 & 29 & 153 & 138 & 153 \\
\hline & 50 & 32 & 394 & 143 & 207 \\
\hline & 200 & 27 & 545 & 127 & 238 \\
\hline
\end{tabular}

a Average of 3 separate Expts.

b Negative control.

of benzidine, a well known bladder carcinogen-9). Morton et al. ${ }^{7)}$ obtained evidence for the fact that the metabolism of benzidine could include the following sequence : benzidine $\rightarrow \mathrm{AB} \rightarrow \mathrm{DAB} \rightarrow N$-hydroxy $-N, N^{\prime}$-diacetylbenzidine $\rightarrow$ nucleic acid binding. The authors stated that $N$-hydroxy- $N, N^{\prime}$-diacetylbenzidine might participate in the induction of tumors by benzidine. The present study suggests that a biotransformation, $N$-acetylation $\rightarrow N, N^{\prime}$-diacetylation, may take place in the metabolism of $o$-tolidine as well as of benzidine.

Both $\mathrm{CH}_{3}-\mathrm{AB}$ and $\mathrm{CH}_{3}$-DAB showed the mutagenic activities with microsomal activation. This suggests that these $N$-acetylated arylamines might be metabolized to $N$-acetyl- $N$-hydroxy compounds by mixed-function oxidases in the liver microsome and act as mutagens.

As a matter of course, there may be other $o$-tolidine metabolites beyond $\mathrm{CH}_{3}-\mathrm{AB}$ and $\mathrm{CH}_{3}-\mathrm{DAB}$ in the urine of the rats treated with $o$-tolidine, whether they are free or conjugated. This is endorsed, for instance, by the fact that the urine extracts derived from $o$-tolidine show the mutagenic activities with or without S9 mix as shown in Table 2. Both $\mathrm{CH}_{3}-\mathrm{AB}$ and $\mathrm{CH}_{3}-\mathrm{DAB}$ do not show mutagenicity in the absence of S9 mix as demonstrated in Table 4. It seems, however, that the strong mutagenicity of the urine extracts derived from $o$-tolidine in the presence of $\mathrm{S} 9 \mathrm{mix}$ is greatly responsible for $\mathrm{CH}_{3}-\mathrm{AB}$ which has been proved as a strong mutagen in the present study.

The experimental result that $\mathrm{CH}_{3}-\mathrm{DAB}$ is less mutagenic than $\mathrm{CH}_{3}-\mathrm{AB}$ draws 
our attention. In contrast to these $o$-tolidine metabolites, no distinguished differences appear to exist between the intensities of the mutagenicity of $\mathrm{AB}$ and $\mathrm{DAB}$.

Epidemiology suggests that 3,3'-disubstitutes of benzidine such as $o$-tolidine, dianisidine, and 3,3'-dichlorobenzidine are for humans less dangerous than benzidine, although these benzidine derivatives are known to produce tumors in experimental animals ${ }^{10,11)}$.

Mutagenicity relates to the initiation process of chemical carcinogenesis in general, but the mutagenic activity of a chemical is not the only decisive factor of the carcinogenesis by the substance ${ }^{12}$. Nevertheless, it seems an attractive subject whether the difference of mutagenic potency between $\mathrm{CH}_{3}-\mathrm{DAB}$ and DAB is connected with the difference of carcinogenic potency between $o$-tolidine and benzidine.

Apart from the subject associated with $o$-tolidine and its metabolites, we would like to discuss another problem related to the metabolism of Evans Blue, an $o$-tolidine-based azo dye.

Yoshida et $a l .^{13)}$ described that benzidine could be found in the large intestine of the rats to which Direct Deep Black EX, a benzidine-based azo dye, had been orally administered. The authors remarked that the phenomenon could be brought about through the reductive cleavage of the azo linkage by Escherichia coli. The same authors also found that the incidence of bladder cancer was relatively high among the Japanese silk kimono painters who have a custom to lick the paint brush impregnated with benzidine-based dyestuffs ${ }^{14}$.

We succeeded in detecting $A B$ and $D A B$ in the urine of the rats to which Direct Deep Black EX and Congo Red, another benzidine-based azo dye, had been orally given. Moreover, we found the benzidine metabolites in the urine of men who had undergone gastroscopy with Congo Red ${ }^{3}$.

Whether Evans Blue might decompose in the large intestine by the bacterial action has not been tested in the presnt study. It is probable, however, that $o$-tolidine or similar substances can be produced in the bodies of the rats following the oral administration of Evans Blue in the same way as found in the cases of the benzidine-based dyestuffs. It seems that the product might be further metabolized to $N$-acetylated derivatives of $o$-tolidine which would be excreted in the urine. The mutagenicity of the urine extracts derived from Evans Blue which is not a mutagen itself supports this speculation along with the analytical data of the urine extracts.

As benzidine-based azo dyes are manufactured from benzidine, $o$-tolidine-based dyestuffs are usually produced by using $o$-tolidine as a raw material. It goes without saying that workers who are engaged in manufacturing biphenyl-based azo dyes should be protected from exposure to the raw material amines. The present study gives us a warning that not only the raw materials but also the final products might be dangerous if their accidental intake through the mouth were repeated. 


\section{REFERENCES}

1) Chemical Regulation Reporter (1979). Nov. 23, p. 1389.

2) Chemical Week (1979). Nov. 21, p. 14.

3) Tanaka, K., Mii, T., Marui, S., Matsubara, I. and Igaki, H. (1981). Int. Arch. Occup. Environ. Health, 49, 177.

4) Ames, B.N., McCann, J. and Yamasaki, E. (1975). Mutat. Res., 31, 347.

5) Yahagi, T., Nagao, M., Seino, Y., Matsushima, T., Sugimura, T. and Okada, M. (1977). Mutat. Res., 48, 121.

6) Tanaka, K., Marui, S. and Mii, T. (1980). Mutat. Res., 79, 173.

7) Morton, K.C., King, C.M. and Baetcke, K.P. (1979). Cancer Res., 39, 3107.

8) Morton, K.C., Beland, F.A. Evans, F.E. Fullerton, N.F. and Kadlubar, F.F. (1980). Cancer Res., 40, 751.

9) Rapp. N.S., Zenser. T.V., Brown, W.W. and Davis. B.B. (1980). Exp. Ther., 215, 401.

10) IARC (1972). Monographs on the evaluation of carcinogenic risk of chemicals to man., Vol. 1, p. 87.

11) Haley. T.J. (1975). Clin. Toxicol., 8, 13.

12) Scribner, J.D. and Suss, R. (1978). Int. Rev. Exp. Pathol., 18, 137.

13) Yoshida, O., Miyakawa, M., Okada, Y., Ohshiro. K., Harada, T., Machida, S. and Kato, T. (1973). Igaku to Seibutsugaku, 86, 361. (in Japanese).

14) Yoshida, O. and Miyakawa, M. (1973). Proceedings of the 3rd international symposium of the Prince Takamatsu Cancer Research Fund. p. 31. University of Tokyo Press, Tokyo. 